\title{
Predicament and Countermeasures of International Talent Cultivation in Universities of Finance and Economics
}

\author{
Wang XI* \\ International Exchange and Cooperation Department, Tianjin University of Finance and Economics, \\ Tianjin, China \\ 345178910@qq.com \\ ${ }^{*}$ Corresponding author
}

Keywords: International talent, Straining difficulties, Curriculum system.

\begin{abstract}
The aim of this paper is to explore and solve the problems in the process of cultivating international talents in China's universities of finance and economics. Based on on-the-spot method, this paper has offered several countermeasures to these problems by collecting primary information from institutions of higher learning and other departments. The innovation of this paper lies in the proposed practice of strengthening international talent training and the corresponding suggestions.
\end{abstract}

\section{Introduction}

Nurturing talents for the field of finance and economics is of great significance for the development of the social economy.

With the continuous reform of the national economic system, the demand for financial talents is increasing. Characterized as servicing the society, financial professionals provide sufficient guarantees for the development of the local as well as national economy. But nonetheless, there was a shortage of international talents which should not be neglected among college students whose comprehensive ability cannot meet the needs of globalized development.

\section{Problems in the Training of International Talents Majoring in Finance and Economics}

\section{The Lagging Internationalization of Teaching Staff Compared with the Internationalization of Curriculum System}

At present, some colleges and universities pay much more attention to the internationalized curriculum system which includes the recruitment standards of the corresponding graduates, comprehensive quality requirements of the professional talents who specialize in economic management, and the development trend of this industry. Highlighting the training of international talents in finance and economics, this curriculum has opened more bilingual or full English courses, introduced original textbooks in English, and greatly enriched the internationalization of curriculum teaching.

However, faced with the ever-increasing internationalized courses, the shortage of international teachers is left in an embarrassing situation. As traditional theoretical-teaching teachers have difficulties in adopting themselves to internationalized courses, it's urgent for all universities to build a highly-internationalized faculty that is skillful in theory, foreign language and experienced in running an international entity.

For the time being, some universities have relieved the tension to a certain extent through short-term training, introduction of overseas talents, and recruitment of foreign teachers. However, how to construct a normal mechanism for the internationalization of teachers that matches international curriculums is still worthy of consideration and research.

\section{The Serious Homogeneity of Talent Training}

The homogenization mainly refers to one thing: most of the internationalized curriculums are English-speaking, which means the use of other languages (such as German, French, Spanish, and 
Vietnamese) is less than that of foreign language teaching. It obviously cannot meet the requirement of international talents as China is building a new open pattern under the "One Belt and One Road" Strategy.

With the deepening of China's "One Belt and One Road" strategy and the construction and development of the China-ASEAN Free Trade Area and China-Korea Free Trade Zone, universities are required to strengthen their non-English courses, such as Russian, Korean, Spanish, Vietnamese and so on, improving students 'cross-language and inter-cultural communication skills.

\section{The Relatively Weak Link in International Teaching Practice}

At present, most colleges and universities mainly adopt the method of classroom teaching to improve students' internationalization ability, totally overlooking the importance of management and assessment of the practical teaching. As a result, this method cannot truly reflect the students' internationalization ability and this situation desperately need to change.

Internship with international companies is an important way to improve the practical skills of students who are majoring in economics and management. For most undergraduates, their internships are arranged by their universities or themselves. There are not much students who can enter multinational corporations in China or local companies with international operations. Students who can go to overseas companies in China are even fewer. It is difficult for universities to simulate the operation mode and operating environment of international companies in a panoramic manner. So, it is necessary for universities to take measures to broaden channels for their international talents and improve teaching evaluation in the process of practice.

\section{The Reason Why the Training of Financial Talents Should be Internationalized}

In the near future, China should the professional teaching concepts and advanced theories of western countries. This process is to push forward a reform on the basis of China's national conditions and to explore the correct path for China's development instead of a copy. Internationalized personnel training in finance and economics will have a major impact on China's economic development. And it is the only way for china to realize the transformation from an economic giant to a superpower.

The strategy of rejuvenating the country through science and education and strengthening the country through talents offer significant guarantee for the sustainable development of China's economy. And the cultivation of international financial and economic talents is an objective requirement for our country. In addition, with the acceleration of the economic globalization, high-quality compound talents with international perspective and basic principles of world economic development are needed for China's economic growth. Therefore, the cultivation of international talents for finance and economics is in line with the need of China's economic growth as universities are the bases of cultivating talents and the training model which is advancing with the times has become a trend.

\section{Training Countermeasures for Financial and International Talents}

\section{Internationalization of the Teaching Staff}

The construction of the international teaching staff is crucial to the training of international talents. So, universities should support the training of internationalized faculty mainly from three aspects: policies, systems, and funds.

First, through absorption, recruitment, and admission of outstanding faculty and scholars from all over the world, so that universities are able to improve their reputation, promotes the teaching quality and the ability of teaching teams.

The second is to ensure the legal status of the international teachers by means of bills and initiatives and provide them with sufficient support and encouragement.

The third is to encourage teachers to make more cross-border exchanges among first-rate universities in various countries in order to promote their ability by means of projects, funding, and cooperation. 


\section{Laying Stress on the Features of International Courses}

The opening of international courses in colleges and universities should be based on their own advantages and serve the national strategy. So, it is suggested that universities should open as much as multilingual international curriculum instead of English courses simply.

First of all, colleges and universities should establish a high-level internationalized curriculum access and project establishment system. And building a curriculum application and approval mechanism according to the objectives and standards of high-level internationalized curriculum construction is also necessary. Besides, to adapt to the development of the Belt and Road Initiative, related courses and systems should be opened up combining its own teaching advantages projects, such as a multilingual national curriculum system.

Secondly, each major should optimize its own curriculum system, rationally allocate the proportion of high-level internationalized courses in each module and organize high-level scholars to take the lead in course application based on its own professional advantages and international talent-training objectives.

Universities will choose the best one after experts have taken a comprehensive check in the objective accuracy, advanced content, scientific design of the curriculum as well as rational teaching staff, obvious teaching effect, and carried out an on-the-spot defense of feasibility, feasibility of construction objectives given by teachers who are in charge of a certain curriculum.

Finally, it is to optimize the teaching content which is the core element of the course, ensuring the quality of the course construction.

The construction of high-level internationalized course content should not only fully reflect the frontiers of the discipline such as the latest progress and latest research methods, but also totally present the cross-convergence of related disciplines. The construction of curriculum content should always focus on systematic knowledge, improved by frontier knowledge, supported by basic knowledge along with related interdisciplinary knowledge. At the same time, universities need to adjust, condense, enrich, and optimize course teaching framework in order to make it in accordance with the development of disciplines, personnel needs, and the actual teaching effectiveness of the curriculum.

By paying much attention to the basic knowledge, the construction of classical theories, the breakthrough of key issues, the teaching of cutting-edge research and emphasizing the systematic and interdisciplinary nature of the curriculum knowledge system and the connection between curriculum content and the frontiers of science and technology and social development, all universities will make great achievement in cultivating their international talents' knowledge acquisition ability, academic identification ability, independent research ability and social adaptability.

\section{Strengthen Practice Exercise of Internationalization Courses}

\section{Combination of Practical Teaching and Social Practice.}

The construction of a practical teaching base is a key link in the implementation of practical teaching, and it is one of the prerequisites for ensuring the quality of international talents. All universities should include the construction of practical teaching bases in the overall planning, increase investment, make full use of social resources, adjust measures to local conditions, and build a practical teaching base that satisfies international talent training through multiple channels.

\section{Establishing Off-campus Practice Bases with Multinational Corporations and Research Institutes.}

Schools cannot provide an international realm of transnational corporations. Therefore, all universities should be integrated with transnational corporations to enable students to improve their practical ability and innovative abilities and develop themselves in all directions in such an international work environment. At the same time, teachers will also find their own teaching deficiencies and improve themselves. 


\section{Organize Various School Activities}

These activities are helpful to improve students' oral expression ability, logical thinking ability, and scientific research ability. Such as international oral English competitions, English research salons and so on. These practical activities will mobilize the students' enthusiasm, improve their practical ability as well as the ability to innovate and express themselves.

\section{References}

[1] Yaping Jing. Research on the Comprehensive Ability Evaluation and Training System of Local University Students in Finance and Economics [D]. University of Electronic Science and Technology, 2016.

[2] Ping Jiang. Exploration of thepath of internationalization of graduate education ——Based on the perspective of education service trade [J]. Higher Education Research, 2014, 17(01): 1-5.

[3] Qiang Li, Wei Wei. Measures and Strategies for Internationalized Talent Cultivation in Economics [J]. Journal of Jilin Institute of Business and Technology, 2014, 30(02):107-109.

[4] Yan Yan. Research on the Constitution and Cultivation of International Sports Talents in Colleges and Universities [D]. Shanghai International Studies University, 2017.

[5] Dan Wang. Research on Internationalization of Talents Training in Universities with Unique Characteristics[D]. Huazhong Agricultural University, 2015.

[6] Yi Sun. An Analysis of the Path to Internationalization of Higher Education Customized Talents Training Model [J]. Educational Theory and Practice, 2015, 35(22): 30-33. 